\title{
The Aspirations of New Technology-Based Firms in CEE and CIS Countries
}

\author{
Przemysław Zbierowski \\ Associate Professor, przemyslaw.zbierowski@ue.katowice.pl \\ University of Economics in Katowice, 1 Maja 50, 40-287 Katowice, Poland.
}

\begin{abstract}
$\mathrm{T}$ he main purpose of this paper is to assess the possible impact of new technology-based firms on the social and economic development of Central and Eastern European (CEE) and Commonwealth of Independent States (CIS) countries by analyzing the share of such firms among entrepreneurs and society and by investigating data on their expected growth, innovativeness, and internationalization. The study contributes to forecasting the future effects caused by NTBFs on the economy of CEE and CIS countries. We use pooled samples from 2013-2015 from the Global Entrepreneurship Monitor for: Russia (pooled sample size: 4,030), Hungary $(6,003)$, Romania $(6,024)$, Poland $(6,001)$, Lithuania $(4,000)$, Latvia $(4,004)$, Estonia $(6,662)$, Czech Republic $(5,009)$, Slovakia $(6,010)$, and Kazakhstan $(4,205)$. Most analyses are based on a oneway ANOVA analysis of the differences in the average size of country indicators for the analyzed countries.

The research results point to significant differences among the analyzed countries. The share of NTBF

owners ranges from $0.7 \%$ (Russia) to almost $5 \%$ (Slovakia, Romania, and Kazakhstan). NTBFs also substantially differ across countries in terms of projected growth (highest in Hungary and lowest in Russia), internationalization (highest in Latvia, lowest in Russia) and innovativeness (highest in Poland, lowest in Kazakhstan). The main limitations of this study are as follows. The sample used was not chosen specifically for the task. Moreover, the assessment of the novelty of the technology is based on the entrepreneur's self-assessment, so we might expect a bias in that regard. The data on projected growth, internationalization, and innovations are just the expectations of the entrepreneurs themselves, so again, bias is expected. The relationships presented in the paper might be strongly influenced by external factors and sample pooling might even magnify that impact. The paper has implications for the policies developed to support entrepreneurship in order to facilitate growth, internationalization, and innovativeness at NTBFs.
\end{abstract}

Keywords: new technology-based firms (NTBFs); early entrepreneurs; CIS countries; CEE countries; innovation; internationalisation.
Citation: Zbierowski P. (2017) The Aspirations of New Technology-Based Firms in CEE and CIS Countries? Foresight and STI Governance, vol. 11, no 3, pp. 50-60. DOI: 10.17323/2500-2597.2017.3.50.60 
$\mathrm{N}$ ew technology-based firms (NTBFs) constitute one of the fastest growing areas in entrepreneurship literature as they are critically important for socioeconomic development. Increasing the number of rapid-growing NTBFs is one of the key priorities of the innovation policy adopted by the European Commission [Grilli, 2014].

Meanwhile, the actual state of and aspirations for ventures started up by entrepreneurs with the use of new technologies in the countries of Central and Eastern Europe (CEE) and the Commonwealth of Independent States (CIS) is a less researched topic. The main purpose of this paper is to assess the possible impact of NTBFs on the social and economic development of the CEE and CIS countries, comparing the share of NTBFs among early entrepreneurs, their aspirations regarding growth, innovativeness, and internationalization. As the paper is rather descriptive, it does not necessarily follow the classic structure of an academic paper. I do not formulate hypotheses, instead, I look at patterns and attempt to jointly analyze and compare various results.

The situation of CEE and CIS countries with regard to business start-ups and especially NTBFs is somewhat special. Aidis, Estrin and Mickiewicz [Aidis et al., 2008, 2012] point out the weak institutions in those countries and argue that the institutional environment is important in explaining the levels of entrepreneurship development. Moreover, they make an observation that freedom from corruption is significantly related to entrepreneurial entry. Estrin, Mickiewicz and Stephan [Estrin et al., 2013] attribute the possible lower levels of entrepreneurial activity to lower levels of social capital (associated with the past's lower level of social entrepreneurship) and the lack or imperfection of formal institutions such as strong property rights. In addition, the technological environment does not support NTBFs as most CEE and CIS countries still have not developed effective frameworks for research and development (R\&D) funding and support at the national level, which is reflected in the low percentage of GDP spent on R\&D (the highest CEE and CIS country in that regard is Czech Republic with about 2\% of GDP spent on R\&D).

\section{Approach}

To undertake an in-depth investigation into the phenomenon of NTBFs, I decided to use data from the Global Entrepreneurship Monitor (GEM). It allows one to investigate entrepreneurs at the very earliest stages of their activity, even before they formally establish a new enterprise [Reynolds, 2017]. Moreover, GEM gathers data based on a representative random sample of at least 2,000 adults in each country taking part in the project each year, which allows one to both compare countries and capture the dynamics of the processes [Kelley et al., 2016]. Finally, using the GEM methodology, one is able to identify those entrepreneurs that use new technologies. The basis for distinguishing start-ups using new technologies is a question included in the APS questionnaire: "How long have the technologies or procedures required for this product or service been available?"'. The GEM does not purposefully identify or define new technology-based firms and makes no separate attempt to analyze ventures using new technologies. NTBFs are elsewhere defined as ventures recently established by a group of entrepreneurs, based on the exploitation of an invention or technological innovation and as firms that employ a high proportion of qualified employees [Campos et al., 2011]. Throughout the paper I use the term NTBF to describe the new venture (up to three and a half years of age) using a technology that has been available for at most five years.

The cyclical research within the framework of the Global Entrepreneurship Monitor allows one to track the dynamics of the analyzed phenomena. However, in order to analyze the characteristics of the entrepreneurs using new technologies, sets of data from 2013-2015 have been accumulated. Such a collection provides a larger research sample, while the period between the outermost points of the study is not too long, so it can be assumed that the external conditions for running a business have not changed substantially. The collection of the research samples resulted in a total sample of 51,948 respondents in CEE and CIS countries. Within this sample, 5,183 persons have been identified as early stage entrepreneurs and included in the TEA (Total Early Stage Entrepreneurial Activity) measure (9.98\%), which covers all entrepreneurs on the market for up to three and a half years, and is further divided into nascent entrepreneurs (up to six months of activity) and new business owners (six months to three and a half years of activity). Among these persons, 628 entrepreneurs declared using the newest technologies (technologies up to one year old) (1.2\% of the total sample, $12.1 \%$ of TEA) while 1,102 reported using new technologies (between one to five years old) ( $2.1 \%$ of the total sample, $21.3 \%$ of TEA). The rest, 3,453 TEA entrepreneurs, declared using technologies invented more than five years ago.

The GEM also distinguishes between the levels of technology for the sector of activity of the entrepreneur, which could also be used as an indicator of the quality of the start-up. However, only 197 entrepreneurs in high-tech industries were identified (3.8\% of TEA) and due to that small number, such a distinction is not appropriate for analysis. In view of such results, it is most expedient to combine the groups of entrepreneurs using the newest and new technologies and analyze them together. There are 1,730 such entrepreneurs in the CEE and CIS sample, which constitutes the foundation for statistical analysis. Moreover, in some cases, taking into consideration only the entrepreneurs using the latest technologies would result in very small numbers of respondents (for example, Russia only has four such persons).

The present study pertains to the comparison of entrepreneurs using new technologies and those using solely technologies that have been available for at least five years. Moreover, CEE and CIS countries are compared to find some interesting patterns in their high-tech entrepreneurship. The subjects of study are 10 CEE, CIS and former USSR countries: Russia (pooled sample size: 4,030), Hungary $(6,003)$, Romania

\footnotetext{
1 There are three possible answers: "less than a year", "between one to five years", "longer than five years". Depending on the answer given, GEM divides entrepreneurs into those using newest technologies (up to one year), new technologies (one to five years) and those not using new technologies (more than five years).
} 
Table 1. Total, TEA, and high-tech TEA sample sizes in CEE and CIS countries, 2013-2015

\begin{tabular}{|c|c|c|c|c|c|c|}
\hline Country & $\begin{array}{c}\text { Sample } \\
\text { size }\end{array}$ & $\begin{array}{l}\text { All } \\
\text { TEA }\end{array}$ & High-tech TEA & TEA & High-tech as \% of TEA & $\begin{array}{l}\text { High-tech as \% of total } \\
\text { population }\end{array}$ \\
\hline Russia & 4030 & 210 & 29 & 5.21 & 13.81 & 0.72 \\
\hline Hungary & 6003 & 533 & 101 & 8.88 & 18.95 & 1.68 \\
\hline Romania & 6024 & 636 & 281 & 10.56 & 44.18 & 4.66 \\
\hline Poland & 6001 & 569 & 148 & 9.48 & 26.01 & 2.47 \\
\hline Lithuania & 4000 & 472 & 165 & 11.80 & 34.96 & 4.13 \\
\hline Latvia & 4004 & 538 & 122 & 13.44 & 22.68 & 3.05 \\
\hline Estonia & 6662 & 702 & 257 & 10.54 & 36.61 & 3.86 \\
\hline Czech Republic & 5009 & 403 & 141 & 8.05 & 34.99 & 2.81 \\
\hline Slovakia & 6010 & 602 & 292 & 10.02 & 48.50 & 4.86 \\
\hline Kazakhstan & 4205 & 518 & 194 & 12.32 & 37.45 & 4.61 \\
\hline
\end{tabular}

(6,024), Poland (6,001), Lithuania (4,000), Latvia (4,004), Estonia (6,662), Czech Republic (5,009), Slovakia $(6,010)$, and Kazakhstan $(4,205)$. Bulgaria and Georgia have been excluded from the list due to the fact that during the research period in question (2013-2015) they participated in the survey only once, resulting in samples of 2,002 and 2,016 respondents, respectively. Also, Georgia left the CIS in 2008. Baltic countries (Lithuania, Latvia, and Estonia) officially do not belong to CEE, it is however interesting to take them into consideration given that they are former USSR countries and are economically similar to CEE countries. Sample sizes for countries differ as some countries took part in the research survey three times in 20132015 (Hungary, Romania, Poland, Estonia and Slovakia) and some countries only participated twice (Russia, Lithuania, Latvia, Czech Republic and Kazakhstan). Sample sizes, the numbers of TEA respondents, and high-tech TEA respondents are presented in Table 1. The results for TEA and high-tech TEA are unweighted, therefore they will slightly differ from official GEM results for which calculating weights are used.

As it can be seen, the TEA and high technology venture results differ substantially among the studied countries. Traditionally the lowest TEA rate in the region is experienced by Russia along with the lowest share of high-tech ventures. The highest TEA is observed in the Baltic countries, but also in Kazakhstan. In terms of the share of high-tech ventures in Romania and Slovakia, it surpasses $40 \%: 44.18 \%$ and $48.5 \%$, respectively.

\section{Socio-demographic characteristics of high-tech entrepreneurs in CEE and the CIS}

Gender and age usually play an important role in the analysis of early entrepreneurs, as they often determine human and social capital. Marlow and McAdam [Marlow, McAdam, 2012] take a feminist perspective in analyzing high-tech female entrepreneurship, but admit that women are the minority when it comes to high-tech business ownership. Mayer [Mayer, 2008] argues that female entrepreneurs are more likely to start firms in predominately female high-tech sectors than in male-dominated high-tech sectors. Moreover, female-dominated high-tech firms are smaller and less profitable than their male counterparts. On the other hand, Tan [Tan, 2008] argues that female entrepreneurs are more willing to take risks that are also associated with using new technologies, which might suggest that the percentage of women among high technology entrepreneurs might be higher than in the group of low technology entrepreneurs. Figure 1 presents the share of male entrepreneurs among high-tech and low-tech venture owners in CEE and CIS countries.

The differences in the shares of male entrepreneurs in high-tech and low-tech ventures are not substantial with two exceptions: Lithuania and Latvia, where there is a larger share of women involved in high-tech start-ups in Latvia, while in Lithuania there is a larger share of men. It is also worth noting that in two CIS countries, Russia and Kazakhstan, the share of women starting up a business is the highest, but also the share of women in high-tech ventures is higher than in low-tech ventures. In Kazakhstan, women starting up a high-tech venture are even in majority, although it must be said that the difference is not statistically significant with a 0.95 confidence interval.

There is some evidence that ventures using new and high technologies are more often started by young entrepreneurs [Cannone et al., 2014; Ouimet, Zarutskie, 2014]. That is partly because young people have a better understanding of new technologies, but also because they are more internationally oriented and tend to import new technologies [Cannone et al., 2014]. Figure 2 presents the research results concerning this phenomenon.

As assumed, in most cases the share of young people (up to 35 years of age) establishing a high-tech business is higher than in low-tech ventures. In Poland, where it is the highest, two thirds of high-tech ventures are started by people in their twenties and early thirties and $27 \%$ of them are started by people under 25 years of age. The two exceptions are Latvia, where high-tech ventures are started on average by people older than those who start low-tech ventures, and Kazakhstan, where there is no difference in that respect.

\section{Self-assessment, the cultural perception of entrepreneurship, and the motives for starting a business in CEE and CIS countries}

Part of the decision to start a business is determined by a potential entrepreneur's self-assessment and on their perception of the external environment, that is, whether or not it would support or hinder the 


\section{Figure 1. Percentage of male respondents among high- and low-tech entrepreneurs} in CEE and CIS countries, 2013-2015

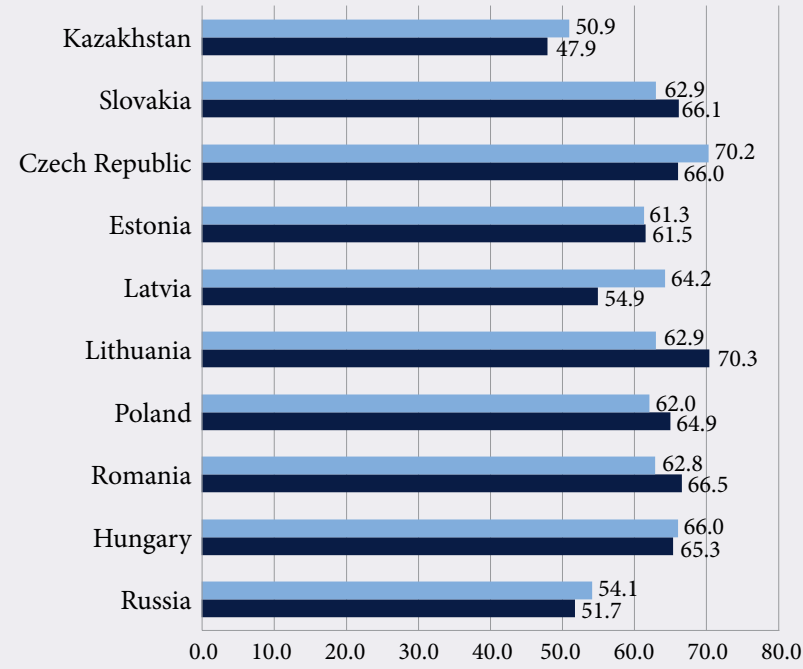

Low tech companies

- High tech companies

Source: compiled by the author.

running of one's own business [Ajzen, 1991, 2011]. Therefore, it is worth analyzing the differences between individual perceptions and the perceptions of a country's business climate by both high-tech and low-tech entrepreneurs by referring to the rate of TEA and high-tech ventures. For these and the following analyses, I use a one-way ANOVA analysis to statistically check the significance of the differences in the average indicators. For each analysis, I present descriptive statistics referring to high-tech venture owners, but I also present sample sizes and averages for low-tech entrepreneurs for the purpose of comparison. Tables 2 and 3 present the results of the analysis of average indicators of the individual perceptions of an entrepreneur. It is reflected in the GEM variable INDSUPyy (Individual Perception of Entrepreneurship Index) ranging from 0 to 3 points and is the result of a few questions referring to knowing other entrepreneurs, perceiving opportunities for business, overcoming the fear of failure, and possessing the appropriate knowledge and skills for running a business.

The results of the one-way ANOVA analysis indicate that there are some statistically significant differences among countries in terms of the self-assessments of entrepreneurs. The highest is the self-assessment in two CIS countries: Russia and Kazakhstan. However, in the case of Russia, a high self-assessment is coupled with the lowest TEA score, while in Kazakhstan, it coincides with one of the highest. Also, in Russia the difference between self-assessments by high-tech entrepreneurs and low-tech entrepreneurs is the highest. On the other hand, in case of Hungary, the self-assessment of entrepreneurs is the lowest for both high-tech

\section{Figure 2. Percentage of entrepreneurs under 35 years of age in CEE} and CIS countries, 2013-2015 (\%)

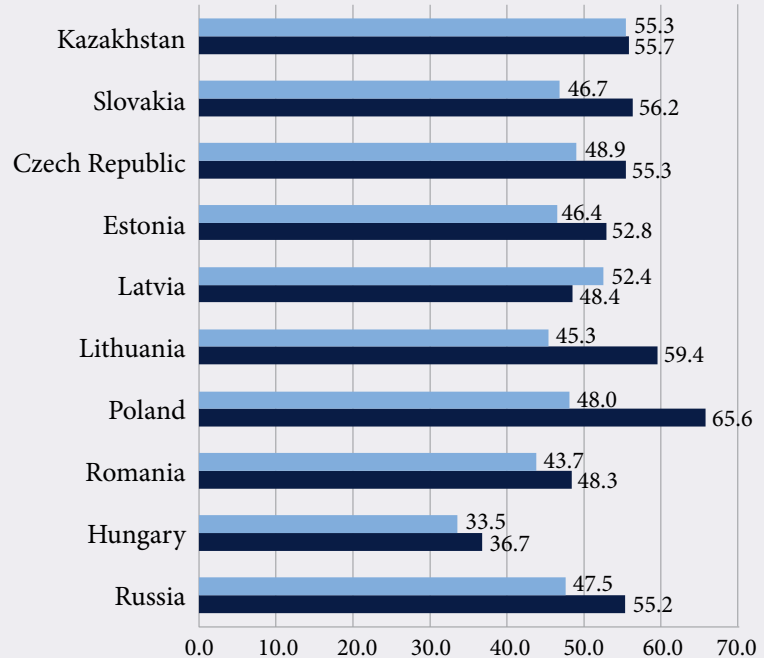

Low tech companies

- High tech companies

Source: compiled by the author. 
Table 2. Descriptive statistics for individual self-assessment by entrepreneurs in CEE and CIS countries, 2013-2015

\begin{tabular}{|c|c|c|c|c|c|c|c|c|}
\hline Countries & $\begin{array}{c}\text { N (high } \\
\text { tech) }\end{array}$ & Mean (high tech) & N (low tech) & Mean (low tech) & SD & SE & $\begin{array}{c}95 \% \text { CR } \\
\text { (low tech) }\end{array}$ & $\begin{array}{c}95 \% \text { CR } \\
\text { (high tech) }\end{array}$ \\
\hline Russia & 26 & 2.38 & 138 & 2.09 & 0.804 & 0.158 & 2.06 & 2.71 \\
\hline Hungary & 87 & 1.69 & 350 & 1.75 & 0.919 & 0.099 & 1.49 & 1.89 \\
\hline Romania & 262 & 1.99 & 320 & 1.84 & 0.835 & 0.052 & 1.89 & 2.09 \\
\hline Poland & 124 & 2.12 & 325 & 2.07 & 0.792 & 0.071 & 1.98 & 2.26 \\
\hline Lithuania & 144 & 1.88 & 247 & 1.93 & 0.960 & 0.080 & 1.72 & 2.03 \\
\hline Latvia & 104 & 2.06 & 346 & 1.87 & 0.857 & 0.084 & 1.89 & 2.22 \\
\hline Estonia & 213 & 2.21 & 356 & 2.25 & 0.815 & 0.056 & 2.10 & 2.32 \\
\hline Czech Republic & 122 & 1.97 & 227 & 1.86 & 0.852 & 0.077 & 1.81 & 2.12 \\
\hline Slovakia & 259 & 1.90 & 254 & 1.94 & 0.848 & 0.053 & 1.80 & 2.00 \\
\hline Kazakhstan & 148 & 2.51 & 219 & 2.37 & 0.742 & 0.061 & 2.39 & 2.63 \\
\hline Total & 1489 & 2.05 & 2782 & 1.98 & 0.865 & 0.022 & 2.01 & 2.09 \\
\hline
\end{tabular}

and low-tech venture owners. Moreover, Hungary is a country where high-tech entrepreneurs have lower individual self-assessments than do low-tech entrepreneurs.

Tables 4 and 5 present the results of the analysis of the perception of the cultural environment, based on the GEM variable CULSUPyy (Cultural Support for Entrepreneurship Index). It is ranged from 0 to 3 points and based on the results of such questions concerning the preference for equal standards of living in society, starting a new business being a desirable career choice, the high social status and respect for those who successfully start a new business, and media coverage of stories about successful new businesses.

The results of cultural perception of entrepreneurship are very similar to results of individual self-assessment by entrepreneurs in those countries. The highest score was achieved by Kazakhstan and then Russia although in the second case the result is much lower than in the individual self-assessment and furthermore was lower among high-tech entrepreneurs than among low-tech entrepreneurs. That phenomenon might be caused by the fact that high-tech entrepreneurs in Russia must overcome greater barriers hindering entrepreneurial activity. The lowest scores for cultural assessment were demonstrated by Hungary, then Poland, Estonia, and Slovakia.

Those low results were also confirmed by the low assessment of entrepreneurial framework conditions (EFCs) by GEM experts in those countries. However, the low assessment and low scores in terms of cultural support does not prevent those countries from achieving strong TEA levels, although in the case of Hungary, this might be the result of a low number of high-tech entrepreneurs.

The GEM methodology makes a distinction between opportunity-based and necessity-based entrepreneurship. The first type is connected with pursuing opportunities - having a good idea for a business and identifying a gap on the market. The second type of entrepreneurship is more or less 'enforced' by a lack of employment or a lack of skills that prevents one from finding satisfactory employment. There is some, albeit fragmented and limited, evidence that high technology ventures are more often based on opportunity rather than on necessity (e.g., [Groen et al., 2008; Gruber, Henkel, 2008]). Intuitively we can assume that the use of new technologies is associated with pursuing opportunity rather than with being pushed into entrepreneurial activity by external circumstances. Figure 3 presents a comparison of the share of opportunity-based entrepreneurs within the high-tech and low-tech groups.

The results confirm our assumptions only to some extent. In some cases, the share of opportunity-based entrepreneurs in the high-tech group is higher than it is in the low-tech group. The biggest difference in that regard is observed in Poland, but large differences exist also in Hungary, the Czech Republic and Kazakhstan. However, for two countries (Russia and Slovakia) the results are contradictory - more opportunity entrepreneurs are observed among low-tech ventures than among high-tech ones. This result might be explained by two distinct factors. In Russia, the TEA indicator is very low, also the share of hightech ventures in the TEA is low. This fact results in a low number of high-tech ventures in general. Therefore, for external, mainly economic reasons, using new technologies might not be considered a good choice and more entrepreneurs often are 'pushed' into using new technologies in order to be competitive on the market. In case of Slovakia, the situation is very different: the distribution of opportunity-based and necessity-based ventures among these two groups of early entrepreneurs is more due to industry or regional conditions. An

Table 3. Results of the one-way ANOVA analysis of individual self-assessment by entrepreneurs in CEE and CIS countries, 2013-2015

\begin{tabular}{|l|r|r|r|r|r|}
\hline & Sum of squares & \multicolumn{1}{|c|}{ df } & Mean square & \multicolumn{1}{c|}{ F } & \multicolumn{1}{c|}{ Sig. } \\
\hline Between groups & 63.831 & 9 & 7.092 & 9.985 & 0.000 \\
\hline Within groups & 1050.491 & 1479 & 0.710 & & \\
\hline Total & 1114.322 & 1488 & & & \\
\hline Source: compiled by the author. & & & \\
\hline
\end{tabular}




\section{Figure 3. Percentage of opportunity-based ventures in CEE and CIS countries, 2013-2015}

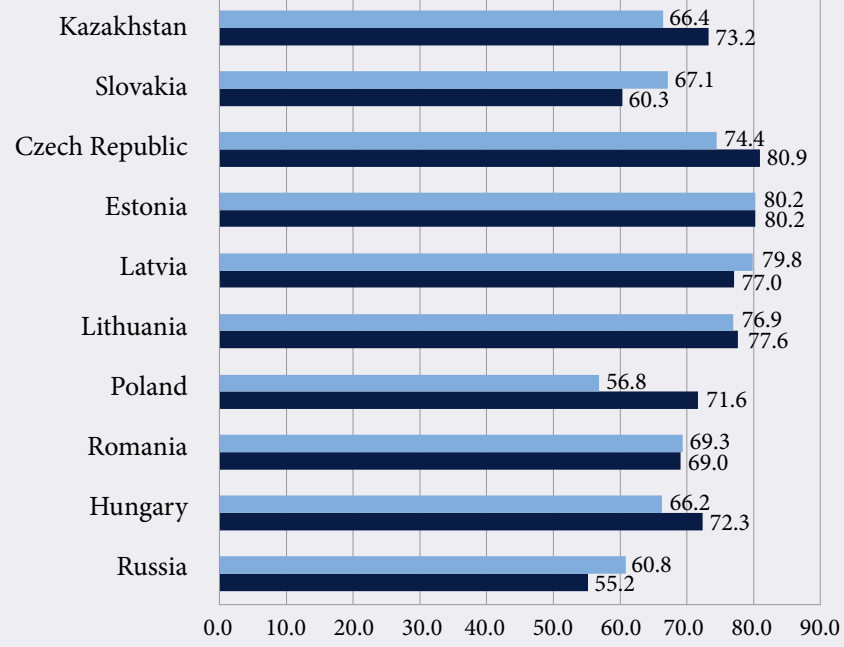

- Low tech companies

- High tech companies

Source: compiled by the author.

explanation might also be found in the geography of the region and the ease of moving entrepreneurial activity to one of the neighboring countries.

\section{Aspirations of high-tech entrepreneurs to grow, innovate and to enter international markets}

GEM projects also focused on the aspirations of the entrepreneurs. This encompasses three types of projections (in the case of nascent entrepreneurs) and assessments (in the case of new business owners): the number of jobs that an entrepreneur wants to create over the next five years (and the current number of jobs as a point of reference), internationalization (the share of customers from outside of the country) and product innovations (the share of customers that consider the product new or unfamiliar). Those three types of aspirations contribute to the quality of the venture. Therefore, the central question that should be asked is: What are the aspirations of high-tech entrepreneurs in CEE and CIS countries?

The first and probably the most obvious, is the association of new technologies and new products. What is especially challenging though is the question of the order in which the process of new product development takes place: are new products 'pushed' forward by new technologies or are new technologies 'pulled' in by new products? There is some evidence to support the first thesis [Gupta, Wilemon, 1990]. In accordance with the GEM's methodology, product innovation is measured by the following question: How many (potential) customers consider your product new or unfamiliar? ( 1 - all, 2 - some, 3 - none). Therefore, the higher the score, the less innovative the product. The results of the one-way ANOVA analysis are presented in Tables 6 and 7.

\section{Table 4. Descriptive statistics for the cultural perception of entrepreneurship in CEE} and CIS countries, 2013-2015

\begin{tabular}{|c|c|c|c|c|c|c|c|c|}
\hline Countries & $\begin{array}{c}N \text { (high } \\
\text { tech) }\end{array}$ & Mean (high tech) & $\mathrm{N}$ (low tech) & Mean (low tech) & SD & SE & $\begin{array}{c}95 \% \mathrm{CR} \\
\text { (low tech) }\end{array}$ & $\begin{array}{c}\text { 95\% CR } \\
\text { (high tech) }\end{array}$ \\
\hline Russia & 24 & 2.13 & 159 & 2.18 & 0.797 & 0.163 & 1.79 & 2.46 \\
\hline Hungary & 96 & 1.63 & 389 & 1.26 & 0.932 & 0.095 & 1.44 & 1.81 \\
\hline Romania & 249 & 2.11 & 312 & 2.04 & 0.955 & 0.061 & 1.99 & 2.23 \\
\hline Poland & 117 & 1.64 & 345 & 1.58 & 1.070 & 0.099 & 1.45 & 1.84 \\
\hline Lithuania & 146 & 1.84 & 241 & 1.73 & 0.852 & 0.071 & 1.70 & 1.98 \\
\hline Latvia & 100 & 1.86 & 355 & 1.77 & 0.932 & 0.093 & 1.68 & 2.04 \\
\hline Estonia & 202 & 1.61 & 338 & 1.60 & 0.956 & 0.067 & 1.48 & 1.75 \\
\hline \multicolumn{9}{|l|}{ Czech Republic } \\
\hline Slovakia & 257 & 1.63 & 274 & 1.42 & 1.011 & 0.063 & 1.51 & 1.75 \\
\hline Kazakhstan & 149 & 2.51 & 261 & 2.43 & 0.827 & 0.068 & 2.38 & 2.64 \\
\hline Total & 1340 & 1.86 & 2674 & 1.73 & 0.990 & 0.027 & 1.81 & 1.92 \\
\hline
\end{tabular}


Table 5. Results of the one-way ANOVA analysis for the cultural perception of entrepreneurship in CEE and CIS countries, 2013-2015

\begin{tabular}{|l|r|r|r|r|r|}
\hline & Sum of squares & \multicolumn{1}{|c|}{ df } & Mean square & \multicolumn{1}{c|}{ F } & Sig. \\
\hline Between groups & 116.744 & 8 & 14.593 & 16.260 & 0.000 \\
\hline Within groups & 1194.536 & 1331 & 0.897 & & \\
\hline Total & 1311.281 & 1339 & & & \\
\hline Source: compiled by the author.
\end{tabular}

As expected, in of all the reviewed countries, product innovation is more likely to be introduced by NTBFs than other types of businesses. Typically, the difference is around 0.3, although there are some countries where it is lower (e.g., Slovakia - 0.15, Czech Republic - 0.16) and countries where it is higher (e.g., Latvia 0.41). Therefore, it might be concluded that early entrepreneurs establishing NTBFs in some countries are more effective than others in transforming new technologies into new products and services. In the case of Slovakia, the low difference between NTBFs and the rest of the ventures might be due to the lower share of opportunity-based entrepreneurs in the former group. When it comes to cross-country differences, the most innovative country in terms of products is Poland and the least innovative is Kazakhstan.

There is a lot of evidence that new technology-based ventures internationalize faster. Symeonidou, Bruneel and Autio [Symeonidou et al., 2017] argue that advances in business process outsourcing and open innovation practices have made the choice of technology commercialization and an internationalization strategy increasingly relevant for new technology-based ventures. They also found that new ventures using IP-based commercialization strategies exhibit higher international intensity after foreign market entry than those with hybrid or product-based strategies. Moreover, it was found that NTBFs internationalize faster and more often, and they also do so earlier. As Johnson [Johnson, 2004] finds, while traditional start-ups generally originate as domestic firms and gradually evolve into multinational enterprises, new technology start-ups increasingly begin as already international firms. Therefore, it can be expected that high-tech entrepreneurs will be more international than low-tech entrepreneurs. At the same time, there is a lot of evidence provided by several authors [Ketkar, Acs, 2011; Chou, 2010; Autio, Acs, 2007] that early internationalization intensity is dependent upon cultural, institutional, macroeconomic and socio-demographic variables. Therefore, it can be assumed that there will be substantial differences among countries regarding the intensity of the internationalization of NTBFs.

The results of the one-way ANOVA analysis concerning the propensity to internationalize are presented in Tables 8 and 9. The analysis is based on the variables 'suexport' and 'omexport' (depending on qualifying the respondent as a start-up or owner-manager). Both variables are based on question: What proportion of your customers normally live outside the country? $(1-$ more than $90 \%, 2-76-90 \%, 3-51-75 \%, 4-$

\section{Table 6. Descriptive statistics for product innovation in CEE and CIS countries, 2013-2015}

\begin{tabular}{|c|c|c|c|c|c|c|c|c|}
\hline Countries & $\begin{array}{c}\mathrm{N} \text { (high } \\
\text { tech) }\end{array}$ & Mean (high tech) & $\mathrm{N}$ (low tech) & Mean (low tech) & SD & SE & $\begin{array}{c}95 \% \text { CR } \\
\text { (low tech) }\end{array}$ & $\begin{array}{c}\text { 95\% CR } \\
\text { (high tech) }\end{array}$ \\
\hline Russia & 29 & 2.31 & 181 & 2.64 & 0.660 & 0.123 & 2.06 & 2.56 \\
\hline Hungary & 101 & 2.31 & 432 & 2.62 & 0.689 & 0.069 & 2.17 & 2.44 \\
\hline Romania & 281 & 2.26 & 355 & 2.55 & 0.785 & 0.047 & 2.17 & 2.36 \\
\hline Poland & 148 & 2.00 & 421 & 2.24 & 0.660 & 0.054 & 1.89 & 2.11 \\
\hline Lithuania & 165 & 2.24 & 307 & 2.48 & 0.717 & 0.056 & 2.13 & 2.35 \\
\hline Latvia & 122 & 2.11 & 416 & 2.52 & 0.702 & 0.064 & 1.98 & 2.23 \\
\hline Estonia & 257 & 2.14 & 445 & 2.46 & 0.744 & 0.046 & 2.05 & 2.24 \\
\hline Czech Republic & 141 & 2.23 & 262 & 2.39 & 0.701 & 0.059 & 2.11 & 2.34 \\
\hline Slovakia & 292 & 2.26 & 310 & 2.41 & 0.683 & 0.040 & 2.18 & 2.34 \\
\hline Kazakhstan & 194 & 2.37 & 324 & 2.74 & 0.687 & 0.049 & 2.27 & 2.46 \\
\hline Total & 1730 & 2.22 & 3453 & 2.50 & 0.719 & 0.017 & 2.19 & 2.25 \\
\hline
\end{tabular}

\section{Table 7. Results of the one-way ANOVA analysis for product innovation in CEE and CIS countries, 2013-2015}

\begin{tabular}{|l|r|r|r|r|r|}
\hline & Sum of squares & df & Mean square & F & Sig. \\
\hline Between groups & 16.366 & 9 & 1.818 & 3.565 & 0.000 \\
\hline Within groups & 877.285 & 1720 & 0.510 & & \\
\hline Total & 893.651 & 1729 & & & \\
\hline \\
Source: compiled by the author.
\end{tabular}


Table 8. Descriptive statistics for internationalization in CEE and CIS countries, 2013-2015

\begin{tabular}{|c|c|c|c|c|c|c|c|c|}
\hline Countries & $\begin{array}{c}\text { N (high } \\
\text { tech) }\end{array}$ & Mean (high tech) & N (low tech) & Mean (low tech) & SD & SE & $\begin{array}{c}95 \% \text { CR } \\
\text { (low tech) }\end{array}$ & $\begin{array}{c}\text { 95\% CR } \\
\text { (high tech) }\end{array}$ \\
\hline Russia & 26 & 6.58 & 160 & 6.68 & 1.501 & 0.294 & 5.97 & 7.18 \\
\hline Hungary & 98 & 5.51 & 407 & 5.65 & 1.459 & 0.147 & 5.22 & 5.80 \\
\hline Romania & 257 & 5.09 & 317 & 5.52 & 1.818 & 0.113 & 4.86 & 5.31 \\
\hline Poland & 146 & 5.34 & 405 & 5.87 & 1.716 & 0.142 & 5.06 & 5.62 \\
\hline Lithuania & 160 & 5.39 & 288 & 5.44 & 1.602 & 0.127 & 5.14 & 5.64 \\
\hline Latvia & 117 & 5.01 & 383 & 5.51 & 1.827 & 0.169 & 4.67 & 5.34 \\
\hline Estonia & 227 & 5.41 & 380 & 5.51 & 1.925 & 0.128 & 5.16 & 5.67 \\
\hline Czech Republic & 137 & 5.50 & 250 & 5.62 & 1.410 & 0.120 & 5.27 & 5.74 \\
\hline Slovakia & 277 & 5.27 & 296 & 5.49 & 1.446 & 0.087 & 5.10 & 5.45 \\
\hline Kazakhstan & 151 & 5.98 & 227 & 6.37 & 1.426 & 0.116 & 5.75 & 6.21 \\
\hline Total & 1596 & 5.38 & 3113 & 5.70 & 1.672 & 0.042 & 5.30 & 5.47 \\
\hline
\end{tabular}

$26-50 \%, 5-11-25 \%, 6-10 \%$ or less, $7-$ none). Therefore, the higher the score (mean) the lower the internationalization of the venture.

As the data of Tables 8 and 9 show, the differences among the countries are quite substantial. Russia and Kazakhstan had the lowest scores. In Russia, most entrepreneurs (both high-tech and low-tech) never internationalize. Intermediate internationalization is experienced by Hungary, Poland, Lithuania, Estonia, the Czech Republic and Slovakia, and the highest level of internationalization takes place in Romania and Latvia.

The level of early internationalization is due to two major factors: the institutional environment and market size. An analysis of data collected by Cahen, Lahiri and Borini [Cahen et al., 2016] through a questionnaire survey revealed three important barriers to internationalization: external (institutional) barriers, internal (organizational capability) barriers, and human resource barriers. In addition Muralidharan, Pathak, and Laplume [Muralidharan et al., 2015] conclude that early internationalization by new technology ventures may depend upon specific features of their home countries, such as the institutional environment. Those with supportive home country conditions may be more likely to go international in order to gain access to new markets. Moreover, their results indicate that a strong regulatory environment and smaller home market size both support early internationalization. Interaction results also indicate that in the case of a smaller home market, a strong regulatory environment is required for the early internationalization of technology entrepreneurs.

Therefore, the lowest score for Russia might be explained by three factors. First of all, the Russian market is the largest of all analyzed countries as the population is the most numerous. Secondly, the structure of Russian economy is quite specific with a number of very large companies that tend to concentrate smaller companies around them. Lastly, the regulatory environment in Russia does not support internationalization, as follows from the assessment of the entrepreneurial ecosystem taken from GEM National Expert Survey data, 'government policies for support and relevance initiatives' and 'government policies for taxes and bureaucracy' are assessed at the level of 3 on a scale of 1 to 9.

The countries with the highest intensity of NTBF internationalization are Romania and Latvia. Interestingly, those countries also experience also the highest difference between the intensity of internationalization at high-tech and low-tech ventures in the early stages of activity. For other countries, the differences are not as substantial, with the exception of Poland, where the difference is also about 0.5 . Polish low-tech ventures are third lowest in the intensity of internationalization among the reviewed countries, but high-tech ventures hold fourth place.

The last GEM index of entrepreneurial aspirations is the number of jobs that an entrepreneur wants to create in the next five years. There is some evidence that NTBF businesses are growing faster. Almus and Nerlinger [Almus, Nerlinger, 1999] prove that NTBFs achieve on average higher growth rates than young non-innovative firms. They even argue that for the latter the number of jobs destroyed by closures, etc., is greater than the number of new jobs at growing and expanding firms. Moreover, there is evidence that the growth of new businesses is dependent upon country and even local characteristics. According to [North,

\section{Table 9. Results of the one-way ANOVA analysis for internationalization in CEE} and CIS countries, 2013-2015

\begin{tabular}{|l|r|r|r|r|r|}
\hline & Sum of squares & \multicolumn{1}{|c|}{ df } & Mean square & \multicolumn{1}{|c|}{ F } & \multicolumn{1}{c|}{ Sig. } \\
\hline Between groups & 137.348 & 9 & 15.261 & 5.602 & 0.000 \\
\hline Within groups & 4320.207 & 1586 & 2.724 & & \\
\hline Total & 4457.556 & 1595 & & & \\
\hline Source: compiled by the author.
\end{tabular}


Table 10. Descriptive statistics for firm growth in CEE and CIS countries, 2013-2015

\begin{tabular}{|c|c|c|c|c|c|c|c|c|}
\hline Countries & $\begin{array}{c}N \text { (high } \\
\text { tech) }\end{array}$ & Mean (high tech) & N (low tech) & Mean (low tech) & SD & SE & $\begin{array}{c}\text { 95\% CR } \\
\text { (low tech) }\end{array}$ & $\begin{array}{c}\text { 95\% CR } \\
\text { (high tech) }\end{array}$ \\
\hline Russia & 28 & 5.64 & 180 & 5.61 & 8.786 & 1.660 & 2.24 & 9.05 \\
\hline Hungary & 99 & 17.92 & 421 & 9.04 & 48.050 & 4.829 & 8.34 & 27.50 \\
\hline Romania & 279 & 13.46 & 350 & 14.85 & 33.942 & 2.032 & 9.46 & 17.46 \\
\hline Poland & 146 & 9.26 & 408 & 7.57 & 21.619 & 1.789 & 5.72 & 12.80 \\
\hline Lithuania & 163 & 8.69 & 303 & 7.82 & 26.239 & 2.055 & 4.63 & 12.75 \\
\hline Latvia & 120 & 13.02 & 412 & 11.28 & 34.632 & 3.161 & 6.76 & 19.28 \\
\hline Estonia & 254 & 8.23 & 441 & 5.83 & 25.011 & 1.569 & 5.14 & 11.32 \\
\hline Czech Republic & 141 & 8.59 & 261 & 7.70 & 22.907 & 1.929 & 4.77 & 12.40 \\
\hline Slovakia & 288 & 14.59 & 306 & 8.68 & 41.275 & 2.432 & 9.80 & 19.37 \\
\hline Kazakhstan & 194 & 17.48 & 321 & 7.50 & 49.438 & 3.549 & 10.48 & 24.48 \\
\hline Total & 1712 & 12.21 & 3403 & 8.75 & 34.901 & 0.844 & 10.56 & 13.87 \\
\hline
\end{tabular}

Smallbone, 1995; Storey, 1994] there is a strong correlation between local characteristics and firm growth In terms of country-level influence the most frequently mentioned factors are wage and salary rates, which are interpreted as a cost factor preventing the hire of new employees and therefore have a negative influence on growth [Rees, Stafford, 1986; Oakey, 1994]. Taking all of the above into consideration, both the positive difference between NTBFs and low-tech firms and the variation among countries in terms of job creation should be observed. The results of the one-way ANOVA analysis are presented in Tables 10 and 11. The variable taken into consideration is the increase in the number of jobs (TEAJOBGR). Outliers of above 300 new jobs have been excluded from the analysis as being decidely too optimistic or abstract answers. They were replaced with the value of 300 .

The analysis yielded some surprising results. First of all, as expected, the projected job creation is higher for NTBFs than for the rest of early entrepreneurs. There is one exception, Romania, where high-tech entrepreneurs declare lower anticipated job creation than their low-tech counterparts. That might be caused by the very high share of NTBFs among TEA entrepreneurs, which might limit their growth. Secondly, the differences among countries are substantial. Russian early entrepreneurs had the lowest projections for growth with no substantial differences between high-tech and low-tech ventures. The highest growth aspirations were expressed by NTBF owners from Hungary and Kazakhstan. In those two cases the difference between high-tech entrepreneurs and the remaining enterprises was the most substantial. The first group declared on average the willingness to create two times as many jobs as the latter. To further analyze the growth patterns of NTBFs and other companies, one must focus on rapidly growing businesses, where the owners hope to create at least 19 jobs over next five years and increase employment by at least $50 \%$ (Figure 4).

The analysis of rapidly growing NTBFs partially confirms the analysis of average job creation. Again Hungary stands out as a country with very high growth potential for high-tech entrepreneurs. Two out of five declare that they will create at least 19 new jobs. Again, Romania is the country (along with the Czech Republic) with the smallest difference between high-tech and low-tech entrepreneurs in terms of growth potential.

When analyzing those results, two factors must be taken into consideration: the pattern of NTBF growth over time and the external environment. Grilli [Grilli, 2014] draws attention to a number of country-level determinants of NTBF growth, for instance, the social and regulatory burdens arising from (honest) firm failure, the local nature of the venture capital industry, the "halo and certification" effect of direct public subsidies and grants given to NTBFs. Furthermore, as Rizzo, Nicolli and Ramaciotti [Rizzo et al., 2013] prove in their research, the process of NTBF growth is even less linear than the process of non-technologybased venture growth. Therefore, both factors are to be considered when considering the impact of a specific environment on NTBF growth and, secondly, when planning activities aimed at supporting the growth of NTBFs.

\section{Conclusions - the capacity of NTBFs to contribute to economic and social development}

The present study provides a diverse and complex picture of the capacity of NTBFs to contribute to economic and social growth. To conclude, I will highlight the most important results. First of all, there is great variety in the shares of NTBFs in the TEA sample across countries, which range from $13.8 \%$ (Russia) to $48.5 \%$

Table 11. Results of the one-way ANOVA analysis for firm growth in CEE and CIS countries, 2013-2015

\begin{tabular}{|l|r|r|r|r|r|}
\hline & Sum of squares & \multicolumn{1}{|c|}{ df } & Mean square & \multicolumn{1}{|c|}{ F } & Sig. \\
\hline Between groups & 21123.384 & 9 & 2347.043 & 1.936 & 0.043 \\
\hline Within groups & 2063012.942 & 1702 & 1212.111 & & \\
\hline Total & 2084136.327 & 1711 & & & \\
\hline Source: compiled by the author.
\end{tabular}




\section{Figure 4. The share of rapidly growing ventures in CEE and CIS countries, 2013-2015}

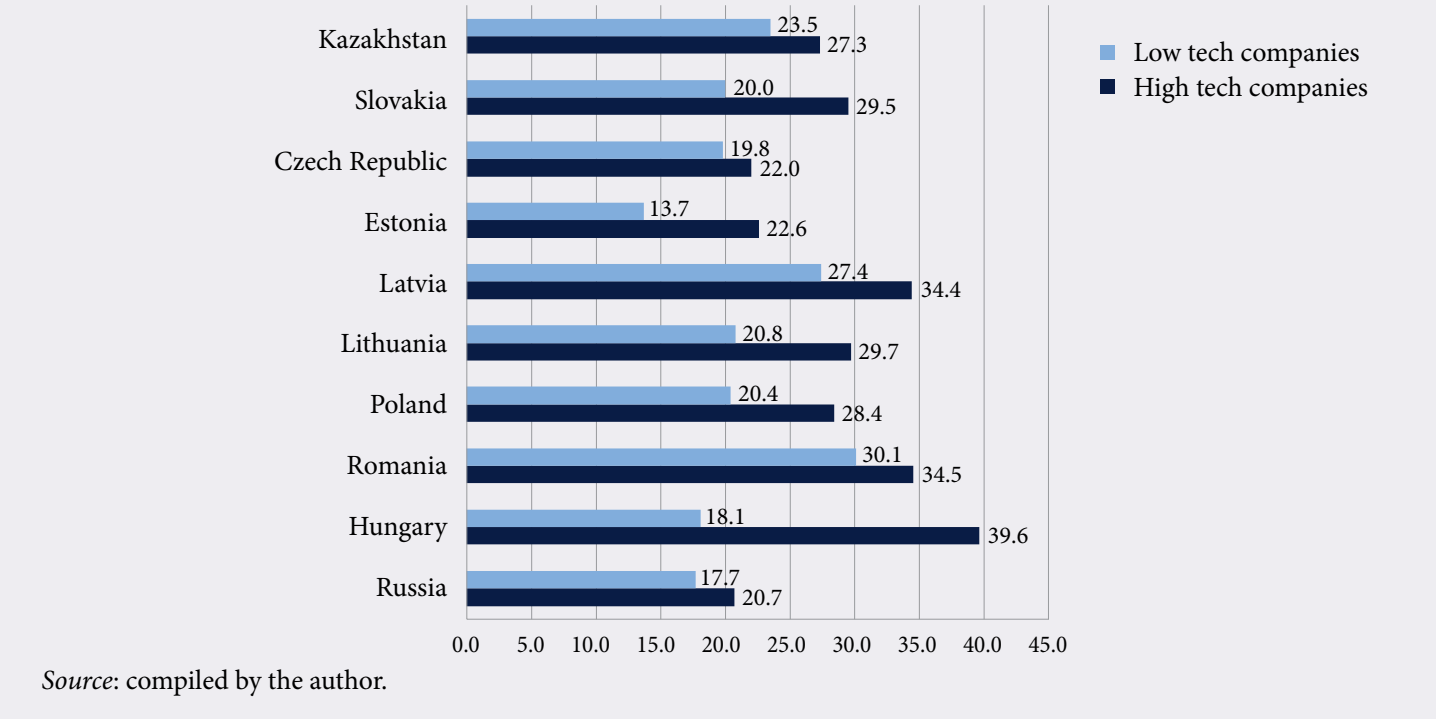

(Slovakia). When considered together with the level of TEA, the effect is doubled and consequently the share of early stage (up to 3.5 years of activity) NTBF owners ranges from $0.7 \%$ (Russia) to almost 5\% (Slovakia, Romania and Kazakhstan). That difference alone might have a serious impact on the capacity of hightech new ventures to affect economic and social development. Moreover, when combined with the growth potential of NTBFs, the impact might even be magnified, as declarations concerning future employment also significantly differ. For instance, if the growth projections for the three countries with the highest shares of high-tech venture owners in society (Slovakia, Romania, and Kazakhstan) are met, then NTBFs would create jobs for about $60-70 \%$ of population over next five years (compared to about $4 \%$ in Russia). This, of course, is not realistic because such projections are highly overconfident [Navis, Ozbek, 2017; Koellinger et al., 2007] and there is also high potential for failure among NTBFs. However, the combination of the number of high-tech ventures and their growth aspirations (even if they are only declared) point to huge differences in the capacity for job creation among the various CEE and CIS countries.

Another finding concerns the differences in the internationalization of NTBFs between the analyzed countries. Clearly willingness to internationalize is dependent upon two factors: the institutional regulatory environment and the size of the domestic market. Therefore, entrepreneurs in big CIS countries like Russia and Kazakhstan are less inclined to internationalize due to the opportunities available on the domestic market. Moreover, in light of research carried out by [Coeurderoy, Murray, 2008], it has to be noted that NTBFs embarking on a strategy of rapid internationalization choose foreign markets that minimize transaction costs and the related risks of failure. Young entrepreneurial firms choose to enter foreign markets that offer better regulatory protection for their intellectual property. This decision is moderated by the home country's regulatory regime.

Although a sample of ten countries is too small to draw definite conclusions, some patterns are discernible. For instance, countries with high TEA rates also have a high share of opportunity-based entrepreneurship. This, for example, is clearly visible in Baltic countries. At the same time, there are some expectations that were contradicted by our data. For instance, opportunity-based entrepreneurship should result in higher product innovation, but that effect was not observed. Countries with the highest share of opportunity entrepreneurs (Czech Republic, Lithuania, Latvia, and Estonia) are only average in product innovation. Another missing relationship is the one expected between the individual self-assessment and/or cultural perception of entrepreneurship and the TEA rate and the share of opportunity-based entrepreneurship. In CIS countries, the self-assessment by early entrepreneurs was very high, but it does not result in high TEA or opportunity-based entrepreneurship. On the other hand, countries with a low cultural perception of entrepreneurship (Poland, Hungary, Slovakia, and Estonia) enjoy rather satisfactory TEA rates.

The study contributes to forecasting the future effects of NTBFs on the economies of CEE and CIS countries, however, there are some limitations. First of all, the sample was not chosen specifically for this study. Even though the Global Entrepreneurship Monitor is robust, it captures only ventures using new technologies, therefore we cannot be sure that those are actually high technologies. Moreover, the assessment of the novelty of a given technology was based on an assessment by the entrepreneurs themselves, so we might expect some bias in that regard. Secondly, the data on aspirations for growth, internationalization, and innovation are simply the projections of the entrepreneurs, so again, some bias is expected. Finally, the relationships presented in the paper might be strongly influenced by external factors and sample pooling might even magnify that impact. Taking all these limitations into consideration, the patterns presented in the paper remain significant for forecasting this future socioeconomic development of the studied countries. 


\section{References}

Aidis R., Estrin S., Mickiewicz T. (2008) Institutions and entrepreneurship development in Russia: A comparative perspective. Journal of Business Venturing, vol. 23, no 6, pp. 656-672.

Aidis R., Estrin S., Mickiewicz T. (2012) Size matters: Entrepreneurial entry and government. Small Business Economics, vol. 39, no 1, pp. 119-139.

Ajzen I. (1991) The theory of planned behaviour. Organizational Behavior \& Human Decision Processes, vol. 50, no 2, pp. 179-211.

Ajzen I. (2011) The theory of planned behavior: Reactions and reflections. Psychology \& Health, vol. 26, no 9, pp. 1113-1127.

Almus M., Nerlinger E.A. (1999) Growth of New Technology-Based Firms: Which Factors Matter? Small Business Economics, vol. 13, no 2, pp. 141-154.

Autio E., Acs Z. (2007) Individual and country-level determinants of growth aspiration in new ventures. Paper presented at the Babson Conference on Enterpreneurship Research, Madrid, June 6-9, 2007.

Cahen F.R., Lahiri S., Borini F.M. (2016) Managerial perceptions of barriers to internationalization: An examination of Brazil's new technology-based firms. Journal of Business Research, vol. 69, no 6, pp. 1973-1979.

Campos E.B., Somoza M.L., Salmador M.P. (2011) CoPs \& Organizational Identity. Handbook of research on communities of practice for organizational management and networking: Methodologies for competitive advantage (eds. O.R. Hernaez, E.B. Campos), Hershey, PA: IGI Global, pp. 308-336.

Cannone G., Pisoni A., Onetti A. (2014) Born global companies founded by young entrepreneurs. A multiple case study. International Journal of Entrepreneurship \& Innovation Management, vol. 18, no 2/3, pp. 210-232.

Chou L. (2010) Cultural ecology: An environmental factor of born globals' success. Review of Business Research, vol. 10, pp. 108-114.

Coeurderoy R., Murray G. (2008) Regulatory environments and the location decision: Evidence from the early foreign market entries of new-technology-based firms. Journal of International Business Studies, vol. 39, no 4, pp. 670-687.

Estrin S., Mickiewicz T., Stephan U. (2013) Entrepreneurship, social capital, and institutions: Social and commercial entrepreneurship across nations. Entrepreneurship Theory and Practice, vol. 37, no 3, pp. 479-504.

Grilli L. (2014) High-Tech Entrepreneurship in Europe: A Heuristic Firm Growth Model and Three "(Un-)easy Pieces" for Policy-Making. Industry \& Innovation, vol. 21, no 4, pp. 267-284.

Groen A.J., Wakkee I.A.M., De Weerd-Nederhof P.C. (2008) Managing Tensions in a High-tech Start-up. International Small Business Journal, vol. 26, no 1, pp. 57-81.

Gruber M., Henkel J. (2008) New ventures based on open innovation - An empirical analysis of start-up firms in embedded Linux. International Journal of Technology Management, vol. 33, no 4, pp. 356-372.

Gupta A.K., Wilemon D.L. (1990) Accelerating the Development of Technology-Based New Products. California Management Review, vol. 32, no 2, pp. 24-44.

Johnson J.E. (2004) Factors Influencing the Early Internationalization of High Technology Start-ups: US and UK Evidence. Journal of International Entrepreneurship, vol. 2, no 1/2, pp. 139-154.

Kelley D., Singer S., Herrington M. (2016) Global Entrepreneurship Monitor 2015/16 Global Report, London: GERA.

Ketkar S., Acs Z. (2011) Cultural burdens and institutional blessings: Internationalization by SMEs from emerging countries. Paper presented at 2011 Academy of Management Annual Meeting, San Antonio.

Koellinger Ph., Minniti M., Schade Ch. (2007) "I think I can, I think I can": Overconfidence and entrepreneurial behaviour. Journal of Economic Psychology, vol. 28, no 4, pp. 502-527.

Marlow S., McAdam M. (2012) Analyzing the Influence of Gender Upon High-Technology Venturing Within the Context of Business Incubation. Entrepreneurship: Theory \& Practice, vol. 36, no 4, pp. 655-676.

Mayer H. (2008) Segmentation and Segregation Patterns of Women-Owned High-Tech Firms in Four Metropolitan Regions in the United States. Regional Studies, vol. 42, no 10, pp. 1357-1383.

Muralidharan E.K., Pathak S., Laplume A.O. (2015) Internationalization by technology entrepreneurs: A multilevel study. Academy of Management Annual Meeting Proceedings. Режим доступа http://proceedings.aom.org/ content/2015/1/17571.short?rss=1, дата обращения 14.03.2017.

Navis Ch., Ozbek O.V. (2017) Why Context Matters: Overconfidence, Narcissism, and the Role of Objective Uncertainty in Entrepreneurship. Academy of Management Review, vol. 42, no 1, pp. 148-153.

North D., Smallbone D. (1993) Employment Generation and Small Business Growth in Different Geographical Environments. Paper presented at the 16th ,National Small Firms Policy and Research Conference, Nottingham, 17-19 November.

Oakey R.P. (1994) New Technology-based Firms in the 1990s, London: SAGE Publications Ltd.

Ouimet P., Zarutskie R. (2014) Who works for startups? The relation between firm age, employee age, and growth. Journal of Financial Economics, vol. 112, no 3, pp. 386-407.

Rees J., Stafford H. (1986) Theories of Regional Growth and Industrial Location: Their Relevance for understanding High-Technology Complexes. Technology, Regions, and Policy (ed. J. Rees), Totowa: Rowman and Littlefield, pp. 23-50.

Reynolds P.D. (2017) When is a Firm Born? Alternative Criteria and Consequences. Business Economics (forthcoming).

Rizzo U., Nicolli F., Ramaciotti L. (2013) The development process of new technology-based firms. International Journal of Entrepreneurship \& Innovation Management, vol. 17, no 4, pp. 352-369.

Storey D.J. (1994) Understanding the Small Business Sector, London: International Thomson Business Press.

Symeonidou N., Bruneel J., Autio E. (2017) Commercialization strategy and internationalization outcomes in technology-based new ventures. Journal of Business Venturing, vol. 32, no 3, pp. 302-317.

Tan J. (2008) Breaking the "Bamboo Curtain" and the "Glass Ceiling": The Experience of Women Entrepreneurs in High-Tech Industries in an Emerging Market. Journal of Business Ethics, vol. 80, no 3, pp. 547-564. 